УДК 656.025.2

\title{
ДОСЛІДЖЕННЯ ПЕРСПЕКТИВНИХ НАПРЯМКІВ РОЗВИТКУ ПРИМІСЬКИХ ПЕРЕВЕЗЕНЬ
}

Канд. техн. наук Д.В. Константінов, А.О. Штагер

\section{ИССЛЕДОВАНИЕ ПЕРСПЕКТИВНЫХ НАПРАВЛЕНИЙ РАЗВИТИЯ ПРИГОРОДНЫХ ПЕРЕВОЗОК}

Канд. техн. наук Д.В. Константинов, А.О. Штагер

\section{RESEARCH PROSPECTIVE WAYS OF SUBURBAN TRANSPORTATION}

Cand. of techn. sciences D.V.Konstantinov, A.O. Shtager

У статті досліджено проблеми та шляхи розвитку сучасних приміських перевезень залізниць України. Запропоновано подальще розвинення системи приміських перевезень з використанням рейкових автобусів та пасажирської логістики.

Ключові слова: приміські перевезення, розвиток, експлуатація, рейкові автобуси.

В статье исследованы проблемы и пути развития современных пригородных перевозок железных дорог Украины. Предложено дальнейшее развитие системы пригородных перевозок $c$ использованием рельсовых автобусов и пассажирской логистики.

Ключевые слова : пригородные перевозки, развитие, эксплуатация, рельсовые автобусы.

This article explores the problems and ways of development modern suburban transportation of Ukrainian railways. Proposed further development of suburban transportation system with using rail buses and passenger logistics. Effective functioning of rail transport due to the improvement of its organizational structure, the replacement of fixed assets and rolling stock, the introduction of new technologies, the 
provision of new services and capture new sectors of the transport market, increase profitability passenger and integration into the European transport system. In modern conditions of rail transport especially acute are the problems of rising losses from suburban passenger transportation, shortage of suburban rolling stock and passenger falling in many areas. This situation definitely needs to find new ways to improve the situation in the suburban. Problem to interest passengers to rail transport services is becoming increasingly important because of necessity of increase the competitiveness of passenger traffic. There certainly will be useful foreign experience of passenger traffic.

Keywords: local, transportation, development, exploitation, rail buses.

Вступ. Важливою $є$ роль залізниць як складової базової галузі держави. Розвиток залізничного пасажирського транспорту сприяє не тільки розвитку окремих галузей промисловості України (машинобудування, авіабудування, чорної металургії й ін.), але й прискоренню темпів зростання загальнонаціонального промислового виробництва. Значення для економіки країни залізничних пасажирських перевезень визначають густота залізничної мережі на території України та ii геополітичне положення. На ринку пасажирських перевезень залізниці працюють у трьох основних сегментах: міжнародному (18\%), внутрішньому далекому (37\%) і приміському (45\%). Ці показники свідчать про те, що залізничний транспорт перевозить значну частку пасажирів. Завдання - зберегти положення й роль залізниць на ринку перевезень при подальшому збільшенні конкуренції, 3 одночасним зниженням експлуатаційних видатків i залученням додаткової кількості пасажирів, а отже, й додаткових доходів. Для цього необхідно вдосконалити структуру керування й застосовувати більш сучасні концепції й методики керування пасажирським комплексом.

В умовах розвитку транспортної мережі України відповідно до європейських стандартів сучасні пасажирські перевезення мають відповідати вимогам щодо забезпечення високого рівня якості надання послуг та безпеки руху. Тому головним завданням організації пасажирських перевезень у всіх видах сполучень $\epsilon$ повне й своєчасне задоволення потреб населення в пересуваннях при забезпеченні безпеки й зручності поїздки, висока якість обслуговування на вокзалах і в поїздах, надання різноманітних асортиментів послуг, доставки пасажирів від станції відправлення до станції призначення точно за розкладом [1].
Таким чином, ефективне функціонування залізничного транспорту пов'язане 3 удосконаленням його організаційної структури, оновленням основних фондів $\mathrm{i}$ рухомого складу, удосконаленням існуючих та впровадженням новітніх технологій експлуатаційної роботи, наданням нових видів послуг i захопленням нових секторів транспортного ринку, збільшенням прибутковості перевезень пасажирів та інтегруванням до європейської транспортної системи [2].

Актуальність. Уже протягом тривалого часу пасажирський сектор намагається вживати заходи щодо покращення якості обслуговування пасажирів та зниження збитків залізниць, особливо в приміських перевезеннях. Адже залізничний транспорт не в усіх напрямках своєї діяльності $є$ прибутковим. Особливо це стосується пасажирських перевезень, в яких далеко не завжди отримані доходи покривають збитки, при цьому приміські перевезення є повністю збитковими.

Наприклад, збитки від перевезень пасажирів у далекому сполученні на Південній залізниці у 2013 році склали 245, 3 млн грн, у приміському сполученні - 297 млн грн. У 2013 році, порівняно 3 аналогічним періодом 2012 року, спостерігається зростання обсягів збитків від пасажирських перевезень у далекому і приміському сполученні загалом на $1,7 \%[3]$.

При вирішенні питань розвитку та підвищення конкурентоспроможності доцільно використовувати досвід розвинених країн Європи, які характеризуються значно більш розвинутою мережею залізниць та досягненням значної ефективності перевізного процесу, що підтверджують високі рівні прибутків. У даній статті робляться посилання на організацію та ефективність розвитку приміських перевезень закордонних залізниць.

Аналіз останніх досліджень і публікацій. У науковій літературі відомі публікації I.M. Аксьонова, Т.В. Бутько, В.Л. Дикаря, 
В.П. Гудкової, Є.М. Сича, Ю.Ф. Кулаєва, В.Г. Шинкаренка, П.О. Яновського та інших авторів, у яких досліджуються проблеми підвищення якості транспортних послуг, розроблення систем регулювання розмірів руху поїздів, прогнозування пасажиропотоків, які $\epsilon$ основою для подальшого дослідження проблеми розвитку пасажирських перевезень, особливо приміського сполучення.

Визначення мети та задачі дослідження. Отже, у зв'язку зі значною збитковістю в умовах підвищення конкурентного тиску з боку автотранспорту, останнім часом $€$ дуже актуальним пошук нових шляхів ефективної організації приміських перевезень, залучення пасажирів до послуг залізничного транспорту та його розвиток в цілому.

Сучасна організація приміських пасажирських перевезень на залізницях України потребує такої системи, яка б змогла адаптувати існуючу систему експлуатації до змін попиту на транспортному ринку 3 урахуванням існуючих особливостей i технічного оснащення приміських перевезень. Приміські пасажиропотоки характеризуються значною сезонною та добовою нерівномірністю, а також притаманною лише їм значною погодинною нерівномірністю у межах доби. Планування приміського руху відбувається наближеними емпіричними способами без урахування існуючого коливання попиту на перевезення, визначення кількості, схем обертання та составності поїздів, а здійснюється, виходячи із обсягів перевезень відповідного періоду минулого року $\mathrm{i}$ не враховує поточних умов, які можуть змінюватися. Тому ефективнішим буде здійснювати коригування організації приміського руху залежно від величини пасажиропотоку, з урахуванням раціонального використання рухомого складу в умовах його дефіциту, що визначає актуальність обраного напрямку дослідження [2].

Основна частина дослідження. У приміському секторі перевозиться понад 360 млн пасажирів на рік, на добу - це більше 1 млн пасажирів. Спостерігається їх величезне соціальне навантаження та пов'язана 3 цим збитковість перевезень. У приміському секторі $70 \%$ пасажирів - це пільгові пасажири, залізничним транспортом перевозиться їх
26 категорій, a компенсацій надходить не більше $50 \%$.

Перший заступник начальника головного управління приміських пасажирських перевезень Укрзалізниці Олександр Гудков в інтерв'ю офіційному прес-центру Укрзалізниці (від 03.12.2013р.) повідомив, що зараз усі приміські перевезення вкрай збиткові і лягають тягарем на залізниці України. Щорічні збитки від організації приміських пасажирських перевезень становлять 3,5 млрд грн. Відсоток покриття їх, тобто доходи, які надходять на одну вкладену гривню, - 12,5 копійки. Незважаючи на це, тарифи приміських перевезень все одно не підвищуються.

Не сприяє інвестиційній привабливості також стан рухомого складу, відсутність коштів на його оновлення та відповідно неможливість забезпечення належного рівня комфорту. Недостатне покриття витрат доходами унеможливлює технічний розвиток приміських перевезень, особливо в умовах значного зносу рухомого складу, який складає $94,3 \%$ від загальної кількості дизель-поїздів і 82,3\% електропоїздів. Для оновлення парку моторвагонного рухомого складу до 2020 року необхідно орієнтовно 15-16 млрд грн. Утримання його, тобто ремонт, техобслуговування тощо потребує ще 2 млрд грн на рік. Зрозуміло, що забезпечення приміських перевезень потребує значних коштів.

Сектор приміських перевезень не $€$ перспективним для комерціалізації, однак ситуація має змінюватись. Зокрема, у проекті нового Закону України «Про залізничний транспорт» вперше створюється правове поле для діяльності інвесторів, у тому числі, приватних, на залізничному транспорті, i зокрема, в секторі пасажирських перевезень. Поява оператора рухомого складу у приміських перевезеннях (чи пасажирських) має бути передбачена та унормована. Однак перспектива появи комерційних перевезень у приміському сполученні в Україні досить віддалена у часі [3].

Також одним із найвигідніших та економічно найефективніших рішень питання розвитку приміських перевезень $\epsilon$ впровадження концепції приміського сполучення 3 використанням рейкових автобусів. Воно надасть можливість 3 комфортом перевозити пасажирів, у тому числі і $з$ малих населених пунктів по малонавантажених напрямках. 
Незважаючи на свої незначні розміри рейковий автобус - дуже місткий вид транспорту, оскільки дозволяє перевозити до 600 пасажирів за один рейс, що у багато разів більше звичайного автобуса підвищеної місткості. Завдяки своїм технічним характеристикам, рейкові автобуси більш економічні, ніж стандартні поїзди. Їх динамічні властивості можна порівняти 3 електричкою (може швидко розганятися і так само легко гальмувати), що є важливим при експлуатації в приміському русі.

Як приклад можемо взяти концепцію рейкових автобусів у Росії, яка активно розвивається. І це не дивно, враховуючи низьку щільність населення країни, велику територію $\mathrm{i}$ наявність великих промислових регіонів, які не мають вираженого економічного центру та розміри території яких за площею перевищують площу деяких великих європейських країн. У Росії географія застосування рейкових автобусів дуже широка: від західного Санкт-Петербурга і промислового Горького, до Тюмені, де рейкові автобуси використовуються як прискорені денні поїзди на маршруті Тюмень - Тобольськ і «ведмежого кута» Красноярського краю Хакасії, де пов'язують регіональний центр Абакан 3 відокремленими районами. При цьому впровадження рейкових автобусів у Росії проходить дуже динамічно. Тільки в 2007 році РЖД придбали у свого національного виробника ВАТ «Метровагонмаш» 52 вагони рейкових автобусів РА-1 і РА-2. Стратегічні плани АТ РЖД з впровадження цього виду залізничної техніки просто грандіозні.

На даний час в Україні курсування рейкових автобусів поступово розвивається, хоча їх кількість по Укрзалізниці досить невелика. Залежно від технічних характеристик та експлуатаційних параметрів 3 урахуванням іноземного досвіду можна виділити три варіанти, в яких використання рейкових автобусів $є$ найбільш ефективним:

1. «Глухі місця», де нормальної дороги 3 твердим покриттям немає, а залізниця прокладена. Тут рейковий автобус може стати справжнім порятунком для місцевих жителів витрати на його утримання істотно менші, ніж експлуатація дизельного поїзда, а маршрутна швидкість набагато більша. Використання рейкового автобуса надасть змогу вивільнити більш місткі дизелі для використання на напружених напрямках.

2. Місця 3 великою перевантаженістю автомобільних доріг, зокрема мегаполіси. Рейковий автобус також потрібний там, де за рахунок перевантаженості доріг поїзд з одного вагона має перевагу перед автобусом. Таке використання рейкових автобусів дозволяе формувати нові напрямки пасажиропотоку. Адже при розвитку маршруту рейковий автобус можна замінити більш місткою електричкою.

3. Використання рейкових автобусів як експресів на промислових i нерозвинених територіях. При цьому використання рейкового автобуса дозволить вибрати кілька яскраво виражених центрів і організувати між ними швидке беззупинкове сполучення [4].

До того ж рейкові автобуси за умови наявності достатньої їх кількості можуть використовуватись у модульній системі руху як групові зчеплення, що може бути дуже актуальним у певні періоди часу доби. Адже, приміські пасажиропотоки характеризуються найбільшим рівнем нерівномірності порівняно 3 іншими видами перевезень. Для прикладу розглянемо динаміку відправлення пасажирів на одному 3 напрямків приміського руху Південної залізниці Смородине - Люботин.

3 діаграми добре видно, що в різні періоди доби кількість відправлених пасажирів значно відрізняється. Зранку спостерігається значне збільшення пасажиропотоків, що обумовлюється необхідністю населення за родом зайнятості здійснення поїздок 3 віддалених населених пунктів до промислових та адміністративних центрів. У пізній ранковий період спостерігається значне зменшення попиту на перевезення, який трохи збільшується в післяобідній час і знову набуває найбільших значень ввечері, коли пасажиропотоки порівняно такі самі великі, як i вранці.

Отже, враховуючи складну ситуацію, що на даний час склалася в системі приміських перевезень, доцільним $€$ розвиток концепції використання рейкових автобусів. Розвиток їх експлуатації надасть змогу підвищити якість обслуговування приміських пасажирів та сприятиме впровадженню системи гнучкого регулювання руху, яка дозволить значно зменшити експлуатаційні витрати та відповідно зменшити збитки Укрзалізниці від приміських перевезень. 


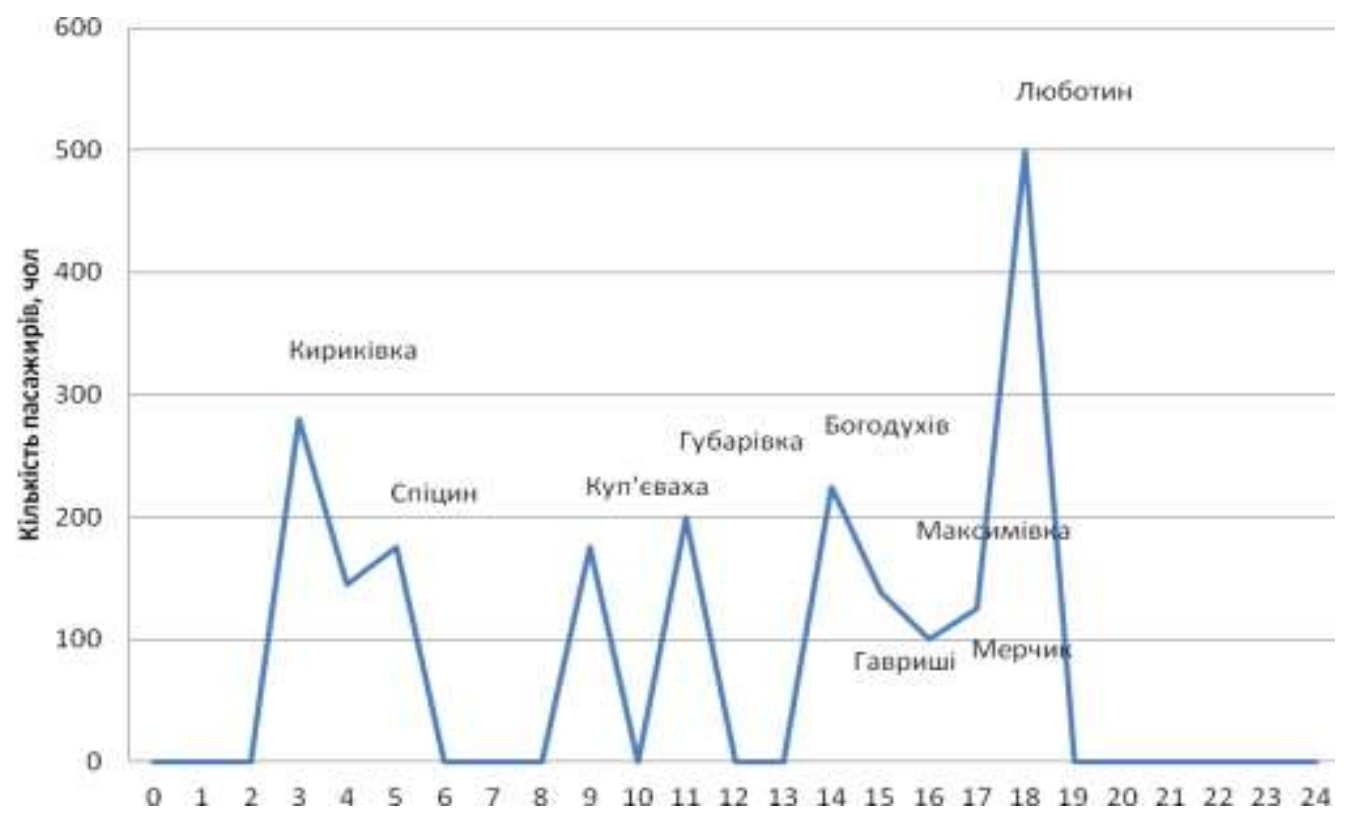

Рис. Динаміка відправлення пасажирів зі ст. Смородине напрямку Смородине - Люботин за одну добу

Удосконалення організації експлуатації рейкових автобусів доцільно реалізувати на основі принципів пасажирської логістики, що передбачають необхідність розробки системи оперативного управління. Мета системи адаптація до попиту, тобто реальних розмірів пасажиропотоків у певні часові інтервали. В сучасних умовах розвитку інформаційних технологій розробка подібної системи доцільна на основі формування СППР (системи підтримки прийняття рішень) у вигляді програмного продукту на АРМ співробітників оперативно-розпорядчих відділів. В основі функціонування СППР має бути закладена технологія пошуку найбільш оптимального варіанта виконання операцій перевізного процесу. 3 урахуванням необхідності пошуку рішень в умовах значної невизначеності (немає можливості точно визначити розміри майбутніх пасажиропотоків) побудову технології оперативного регулювання експлуатації рейкових автобусів має бути здійснено 3 використанням математичного моделювання. Використовуваний математичний апарат має враховувати всі вказані особливості запропонованої системи, а тому доцільне використання таких напрямків, як еволюційні обчислення, нечітка логіка, нейронні мережі.

Висновки. Отже, подальший розвиток приміських перевезень залізниці України потребує якісно нових напрямків досліджень і в першу чергу має бути спрямований на пошук шляхів покращення комфорту пасажирів та зниження експлуатаційних витрат. Тому запропонований розвиток експлуатації рейкових автобусів 3 перспективою розробки СППР для автоматизованого оперативного управління може бути найбільш ефективним напрямком розвитку на даний час.

\section{Список використаних джерел}

1. Сайт Студопедия - лекционный материал для студентов [Электронний ресурс]. - Режим доступа: http://studopedia.net/8_25096_znachennya-pasazhirskih-perevezen.html.

2. Інформаційний центр Київ-диплом. Організація і управління процесами перевезень на напрямку Святошин - Тетерів 3 урахуванням динаміки пасажиропотоку [Електронний ресурс]. Режим доступу: http://www.diplom.kiev.ua/ua/detail.php?id=3619.

3. Офіційний веб-сайт Укрзалізниці [Електронний ресурс]. - Режим доступу: http://uz.gov.ua/press_center/up_to_date_topic/365429/. 


\section{Організація перевезень і управління на транспорті}

4. Консорциум Менеджмент Консалтинг Груп , Сектор пригородных перевозок УЗ - проблемы и перспективы дальнейшего развития [Электронний ресурс]. - Режим доступа: http://mcg.com.ua/news/Press_relizi/Sektor_prigorodnih_perevozok_UZ_-_problemi_i_perspektivi_ dalneyshego_razvitiya.html

5. Кочнев, Ф.П. Оптимальные параметры пригородных пассажирских перевозок [Текст] / Ф.П. Кочнев. - М.: Транспорт, 1975. - 270 с.

6. Сич, Є. М. Пасажирський комплекс залізничного транспорту: розвиток і ефективність [Текст] / Є.М. Сич, В.П. Гудкова. - К.: Аспект-Поліграф, 2004. - 248 с.

7. Пінчук, О.П. Послідовність вирішення проблеми підвищення ефективності приміських пасажирських перевезень [Текст] / О.П. Пінчук // Проблеми економіки транспорту: зб. наук. праць. Дніпропетровськ: Вид-во Дніпропетр. нац. ун-ту залізн. трансп. ім. акад. В. Лазаряна, 2011. - Вип. 1. - С. 102-105.

\section{Рецензент д-р техн. наук, професор Є.С. Альошинський}

Константінов Денис Володимирович, канд. техн. наук, доцент кафедри управління експлуатаційної роботою Української державної академії залізничного транспорту. Тел. 091-901-42-46

Штагер Анна Олегівна, слухач гр. МЗ-ОПУТ-Б-12 Інституту перепідготовки та підвищення кваліфікації Української державної академії залізничного транспорту. Тел. 095-467-05-47.

Konstantinov Denis, cand. of techn. sciences, assistant professor of managing operational work of Ukrainian State Academy of Railway Transport. Tel. 091-901-42-46

Shtaher Anna, listener gr. MZ-OPUT-B-12 Institute of Retraining and Professional Development of the Ukrainian State Academy of Railway Transport. Tel. 095-467-05-47. 